\title{
Pemodelan Harga Cryptocurrency Menggunakan Markov Switching Autoregressive
}

\author{
${ }^{(1)}$ Akhmad Ridho Ashariansyah, ${ }^{(2)}$ Nur Iriawan, dan ${ }^{(3)}$ Adatul Mukarromah \\ ${ }^{(1)(2)(3)}$ Departemen Statistika, Fakultas Sains dan Analitika Data \\ Institut Teknologi Sepuluh Nopember (ITS) \\ Jl. Arief Rahman Hakim, Surabaya 60111 Indonesia \\ e-mail: (1)akhmadridhoashariansyah@gmail.com ${ }^{(2)}$ nur_i@ statistika.its.ac.id ${ }^{(3)}$ adatul@ statistika.its.ac.id
}

\begin{abstract}
Abstrak-Perdagangan merupakan sebuah kegiatan tukar menukar barang atau jasa yang dilakukan manusia untuk memenuhi kebutuhan hidup. Perkembangan sistem pembayaran yang dilakukan umat manusia dimulai dari sistem pertukaran barang atau barter, logam mulia seperti emas dan perak, koin, uang kartal, uang giral, dan uang elektronik (e-money). Selain itu, muncul cryptocurrency yaitu mata uang digital dengan sistem kriptografi dalam setiap proses transaksi datanya tanpa melalui pihak ketiga. Namun cryptocurrency memiliki kelemahan perubahan harga yang sangat besar dalam waktu yang sangat cepat. Pergerakan harga yang berfluktuasi sangat tinggi tersebut menyebabkan kekhawatiran pemilik aset kripto mengalami kerugian, maka pemodelan harga cryptocurrency sangat penting untuk dilakukan agar meminimalisir risiko kerugian. Berdasarkan pola pergerakan harga yang berfluktuasi sangat tinggi yang berbeda tiap periodenya maka dilakukanlah pemodelan harga cryptocurrency menggunakan Markov Switching Autoregressive (MSAR) dengan algoritma Expectation Maximization. Selain meminimkan risiko kerugian, penelitian ini juga ingin mengetahui model MSAR mana yang mampu mengklasifikasikan state dengan baik. Data yang digunakan yaitu harga harian cryptocurrency dengan nilai kapitalisasi pasar terbesar dari September 2015 hingga Januari 2020. Hasil penelitian menunjukkan bahwa bitcoin dan ripple menggunakan model MS(8)AR(1), sedangkan ethereum menggunakan model MS(9)AR(1). Selain itu model MS(8)AR(1) pada data ripple menjadi model dengan nilai akurasi tertinggi dibandingkan model lainnya dalam hal klasifikasi state.
\end{abstract}

Kata kunci: Cryptocurrency, Fluktuasi, MSAR

\section{PENDAHULUAN}

$\mathrm{P}$ erdagangan ialah sebuah kegiatan tukar menukar barang atau jasa yang dilakukan manusia untuk memenuhi kebutuhan hidup. Perkembangan sistem pembayaran yang dilakukan umat manusia dimulai dari sistem pertukaran barang atau barter, logam mulia seperti emas dan perak, koin, uang kartal, uang giral, dan uang elektronik (e-money) [1]. Sistem pembayaran e-money memunculkan kekhawatiran terhadap penyalahgunaan data oleh pihak ketiga, untuk itulah muncul gagasan desentralisasi terhadap pihak ketiga dengan munculnya cryptocurrency. Cryptocurrency merupakan mata uang digital dengan sistem kriptografi dalam setiap proses transaksi datanya tanpa melalui pihak ketiga [2]. Cryptocurrency pertama yang terdesentralisasi secara penuh diberi nama bitcoin. Selain menjadi alat pembayaran bitcoin juga dapat dijadikan alat penyimpanan kekayaan, serta sebagai alat investasi [3]. Beberapa jenis cryptocurrency memiliki batas ketersediaan pasokan, sebagai contoh batas pasokan bitcoin hanya terdapat 21 juta unit [4]. Keterbatasan pasokan ini menjadi salah satu faktor fluktuasi harga cryptocurrency. Fluktuasi harga cryptocurrency dapat merubah harga secara signifikan dalam waktu yang sangat cepat. Hal ini dapat dilihat dari harga bitcoin saat pertama kali digunakan pada bulan Juli 2010 hanya bernilai 0,05 USD/bitcoin, sedangkan harga bitcoin pada akhir tahun 2019 sebesar 7234,44 USD/bitcoin [4]. Perkembangan harga bitcoin yang berfluktuasi sangat tinggi tersebut menyebabkan pola data yang berbeda tiap periodenya. Pola data yang sangat berbeda membuat harga cryptocurrency tidak dapat diselesaikan dengan analisis deret waktu (time series) klasik, sedangkan pemodelan harga cryptocurrency sangat penting untuk dilakukan agar meminimalisir risiko kerugian pemilik aset kripto.

Banyaknya pola data yang terbentuk dari data harga cryptocurrency yang berkaitan dengan deret waktu serta adanya transisi kondisi (regime switching) yang diasumsikan sebagai proses stokastik yang membangkitkan peubah acak tidak teramati bersifat diskrit disebut rantai markov, yang kemudian dikombinasikan dengan model autoregresi sehingga menjadi model Markov Switching Autoregressive (MSAR). Model MSAR diestimasi dengan menggunakan algoritma Expectation Maximization (EM). Algoritma EM terdiri dari dua tahapan. Tahapan pertama yaitu expectation yang mana tahapan ini melibatkan algoritma filtering dan smoothing, untuk menghasilkan estimasi peluang smoothed dari variabel yang tidak teramati. Tahapan selanjutnya maximization, dengan menurunkan hasil smoothing menggunakan fungsi likelihood. Hasil tahapan maximization kemudian dijadikan parameter baru untuk di gunakan ke tahapan expectation kembali, yang mengakibatkan nilai fungsi likelihood selalu meningkat [5]. Penelitian ini bertujuan untuk memodelkan harga cryptocurrency agar tidak mengalami kerugian yang disebabkan oleh fluktuasi harga yang sangat cepat menggunakan Markov Switching Autoregressive dengan algoritma EM dalam pembentukan model. Pada penelitian ini juga ingin diketahui model MSAR mana yang mampu mengklasifikasikan state dengan baik. Data yang digunakan adalah data sekunder berupa historis harga cryptocurrency yang memiliki kapitalisasi pasar terbesar pada Januari 2020, antara lain bitcoin, ripple, dan ethereum.

\section{TINJAUAN PUSTAKA}

\section{A. Analisis Time Series}

Time series merupakan serangkaian observasi terhadap suatu variabel yang diambil secara beruntun berdasarkan interval waktu tertentu [6]. Peramalan time series dapat disebut sebagai tindakan memprediksi masa depan dengan memahami masa lalu [7]. Rangkaian data pada pengamatan time series dinyatakan dengan variabel $Y_{t}$ dimana $t$ adalah indeks waktu urutan pengamatan. 


\section{B. Uji Stasioneritas}

Stasioneritas dapat diartikan tidak terdapat perubahan yang drastis pada data. Stasioneritas terbagi menjadi dua yaitu stasioneritas dalam mean dan varians. Stasioneritas dalam mean diidentifikasi dengan plot time series, plot Autocorrelation Function (ACF), serta uji Augmented Dickey-Fuller (ADF). Data dikatakan tidak stasioner ketika plot time series menunjukkan data berfluktuasi tidak berada disekitar sumbu horizontal, sedangkan pada plot ACF terdapat pola yang turun secara lambat. Sedangkan stasioneritas dalam varians diidentifikasi dengan plot boxcox. Data dikatakan tidak stasioner dalam varians ketika nilai lambda tidak sama dengan 1. Ketidakstasioneran dalam varians dapat diatasi dengan cara transformasi data.

Uji ADF dilakukan dengan hipotesis sebagai berikut:

$H_{0}: \delta=0$ (data tidak stasioner)

$H_{l}: \delta \neq 0$ (data stasioner)

Statistik uji yang digunakan dituliskan pada persamaan (1).

$$
t=\frac{\hat{\delta}}{S E(\hat{\delta})}
$$

Keputusan yang didapatkan akan Tolak $\mathrm{H}_{0}$ jika $|t|>t_{\alpha, d f}$ atau $p$-value $<\alpha$.

Ketidakstasioneran pada data dapat diatasi dengan cara transformasi, salah satu bentuk transformasi yang digunakan yaitu log return, dapat dituliskan pada persamaan (2) [8].

$$
r_{t}=\ln \left(y_{t}\right)-\ln \left(y_{t-1}\right)=\ln \frac{y_{t}}{y_{t-1}}
$$

\section{Model Autoregressive (AR)}

Model autoregressive (AR) adalah model yang menggambarkan variabel dependen dipengaruhi oleh variabel dependen pada periode sebelumnya [9]. Bentuk umum dari proses autoregressive dapat dituliskan pada persamaan (3).

$$
Y_{t}=\phi_{1} Y_{t-1}+\ldots+\phi_{p} Y_{t-p}+u_{t}
$$

dimana $Y_{t}$ merupakan nilai pengamatan, $\phi_{t}$ merupakan koefisien, $u_{t}$ merupakan residual.

\section{Autocorrelation Function (ACF)}

Fungsi autokorelasi (ACF) mengukur bagaimana urutan pengamatan dalam deret waktu berkorelasi satu sama lain. Fungsi autokorelasi antara $Y_{t}$ dan $Y_{t+k}$ dapat dituliskan pada persamaan (4) [10].

$$
A C F(k)=\rho_{k}=\frac{\operatorname{Cov}\left(Y_{t}, Y_{t+k}\right)}{\operatorname{Var}\left(Y_{t}\right) \operatorname{Var}\left(Y_{t+k}\right)}=\frac{\gamma_{k}}{\gamma_{0}}
$$

dimana,

$$
\gamma_{k}=\operatorname{Cov}\left(Y_{t}, Y_{t+k}\right)=E\left(Y_{t}-\mu\right)\left(Y_{t+k}-\mu\right)
$$

\section{E. Markov Switching Autoregressive (MSAR)}

Model markov switching digunakan untuk pemodelan data runtun waktu yang mengalami perubahan kondisi. Perubahan kondisi dalam model markov switching dianggap sebagai peristiwa variabel tak teramati yang disebut dengan state. Model Markov Switching dikombinasikan dengan model runtun waktu Autoregressive untuk mengetahui perubahan kondisi atau pola data runtun waktu. Model MSAR dapat dituliskan pada persamaan (6) [11].

$$
y_{t}-\mu_{s_{t}}=\phi_{1}\left(y_{t-1}-\mu_{s_{t}-1}\right)+\ldots+\phi_{p}\left(y_{t-p}-\mu_{s_{t}-p}\right)+u_{t}
$$

dengan $u_{t} \sim \operatorname{IIDN}\left(0, \sigma_{s t}^{2}\right)$, dimana $Y_{t}$ merupakan nilai pengamatan, $\phi_{t}$ merupakan koefisien, $\mu_{s_{t}}$ merupakan mean yang dipengaruhi perubahan state, $e_{t}$ merupakan residual.

Estimasi parameter dilakukan untuk menduga nilai dari masing-masing parameter pada model. Estimasi parameter model MSAR menggunakan algoritma ExpectationMaximization (EM) [12]. Langkah pertama yang dilakukan sebelum menggunakan algoritma EM yaitu dengan menentukan fungsi densitas. Fungsi densitas model MSAR sebanyak 2 state dapat dituliskan pada persamaan (7).

$$
f\left(y_{t} \mid s_{t}, s_{t-1}, \psi_{t-1}\right)=\frac{1}{\sigma_{k} \sqrt{2 \pi}} \exp \left[-\frac{\left(\left(y_{t}-\mu_{k}\right)-\phi_{1}\left(y_{t-1}-\mu_{k-1}\right)\right)^{2}}{2 \sigma_{k}^{2}}\right]
$$

dimana $\psi_{t-1}$ merupakan nilai pengamatan. State yang tidak teramati dapat diatasi dengan cara sebagai berikut.

1. Menurunkan fungsi densitas gabungan $y_{t}, s_{t}$, dan $s_{t-1}$, bersyarat pengamatan sebelumnya

$$
f\left(y_{t}, s_{t}, s_{t-1} \mid \psi_{t-1}\right)=f\left(y_{t} \mid s_{t}, s_{t-1}, \psi_{t-1}\right) P\left[s_{t}, s_{t-1} \mid \psi_{t-1}\right]
$$

2. Menentukan fungsi desitas $y_{t}$ bersyarat pengamatan sebelumnya dengan menjumlahkan semua kemungkinan densitas bersama dari $s_{t}$ dan $s_{t-1}$.

$$
\begin{aligned}
f\left(y_{t} \mid \psi_{t-1}\right) & =\sum_{s_{t}=1}^{M} \sum_{s_{t-1}=1}^{M} f\left(y_{t}, s_{t}, s_{t-1} \mid \psi_{t-1}\right) \\
& =\sum_{s_{t}=1}^{M} \sum_{s_{t-1}=1}^{M} f\left(y_{t} \mid s_{t}, s_{t-1}, \psi_{t-1}\right) P\left[s_{t}, s_{t-1} \mid \psi_{t-1}\right]
\end{aligned}
$$

Nilai peluang $P\left[s_{t}=j, s_{t-1}=i \mid \psi_{t-1}\right]$ dihitung menggunakan proses filtering dan smoothing sebagai berikut.

\section{Filtering}

Filtering adalah suatu proses yang digunakan untuk mendapatkan nilai peluang suatu state pada waktu ke $t$ berdasarkan nilai pengamatan, dengan langkah-langkah sebagai berikut.

a. Diketahui $P\left[s_{t-1}=i \mid \psi_{t-1}\right]$, dengan $i=1,2, \ldots, M$, pada awal waktu $t$ atau pada iterasi ke-t. Sedangkan $P\left[s_{t}=j, s_{t-1}=i \mid \psi_{t-1}\right]$ dihitung sebagai berikut.

$$
P\left[s_{t}=j, s_{t-1}=i \mid \psi_{t-1}\right]=P\left[s_{t}=j \mid s_{t-1}=i\right] P\left[s_{t-1}=i \mid \psi_{t-1}\right]
$$

b. Saat $y_{t}$ diamati pada akhir waktu $t$, atau pada akhir iterasi ke- $t$.

$$
\begin{aligned}
& P\left[s_{t}=j, s_{t-1}=i \mid \psi_{t}\right]=\frac{f\left(s_{t}=j, s_{t-1}=i, y_{t} \mid \psi_{t-1}\right)}{f\left(y_{t} \mid \psi_{t-1}\right)} \\
& =\frac{f\left(y_{t} \mid s_{t}=j, s_{t-1}=i, \psi_{t-1}\right) P\left[s_{t}=j, s_{t-1}=i \mid \psi_{t-1}\right]}{\sum_{s_{t}=1}^{M} \sum_{s_{t-1}=1}^{M} f\left(y_{t} \mid s_{t}=j, s_{t-1}=i, \psi_{t-1}\right) P\left[s_{t}=j, s_{t-1}=i \mid \psi_{t-1}\right]}
\end{aligned}
$$

diperoleh hasil dari proses filtering

$$
P\left[s_{t}=j \mid \psi_{t}\right]=\sum_{s_{t-1}=1}^{M} P\left[s_{t}=j, s_{t-1}=i \mid \psi_{t}\right]
$$

\section{Smoothing}

Pada proses smoothing nilai probabilitas state dihitung berdasarkan seluruh pengamatan sehingga menghasilkan nilai probabilitas state yang lebih baik dibandingkan proses filtering. Hasil peluang dari proses filtering dilanjutkan dengan pendekatan Kim untuk mendapatkan peluang smoothed [13].

$$
\begin{aligned}
& P\left[s_{t}=j, s_{t+1}=k \mid \psi_{T}\right]=P\left[s_{t+1}=k \mid \psi_{T}\right] P\left[s_{t}=j \mid s_{t+1}=k, \psi_{T}\right] \\
& =\frac{P\left[s_{t+1}=k \mid \psi_{T}\right] P\left[s_{t}=j \mid \psi_{t}\right] P\left[s_{t+1}=k \mid s_{t}=j\right]}{P\left[s_{t+1}=k \mid \psi_{t}\right]}
\end{aligned}
$$

diperoleh hasil dari proses smoothing

$$
P\left[s_{t}=j \mid \psi_{T}\right]=\sum_{k=1}^{M} P\left[s_{t}=j, s_{t+1}=k \mid \psi_{T}\right]
$$


Setelah mendapatkan nilai peluang $s_{t}$ melalui proses filtering dan smoothing maka dapat diperoleh fungsi densitas dari $y_{t}$ sebagai berikut.

$$
f\left(y_{t} \mid s_{t}, s_{t-1}, \psi_{T}\right)=\sum_{j=1}^{M} \sum_{i=1}^{M} f\left(y_{t} \mid s_{t}, s_{t-1}, \psi_{t-1}\right) P\left[s_{t}, s_{t-1} \mid \psi_{T}\right]
$$

Fungsi log-likelihood dapat dituliskan sebagai berikut.

$$
\ln L=\sum_{t=1}^{T} f\left(y_{t} \mid s_{t}, s_{t-1}, \psi_{t}\right)
$$

Nilai masing-masing parameter dapat dihitung dengan memaksimumkan fungsi log-likelihood dengan cara mendiferensialkan fungsi log-likelihood terhadap masingmasing parameter $\theta=\left(\mu_{k}, \sigma_{k}^{2}, \phi_{p}\right)$, didapatkan masing-masing parameter sebagai berikut.

$$
\begin{gathered}
\hat{\mu}_{k}=\frac{\sum_{t=1}^{T} y_{t} P\left[s_{t}=j \mid y_{t}\right]}{\sum_{t=1}^{T} P\left[s_{t}=j \mid y_{t}\right]} \\
\hat{\sigma}_{k}^{2}=\frac{\sum_{t=1}^{T}\left(y_{t}-\hat{\mu}_{k}\right)^{2} P\left[s_{t}=j \mid y_{t}\right]}{\sum_{t=1}^{T} P\left[s_{t}=j \mid y_{t}\right]} \\
\hat{\phi}_{p}=\frac{\sum_{t=1}^{T}\left(\sum_{j=1}^{N}\left(y_{t}-\hat{\mu}_{k}\right) P\left[s_{t}=j \mid \psi_{T}\right]\right)}{\sum_{t=1}^{T}\left(\sum_{j=1}^{N} P\left[s_{t}=j \mid \psi_{T}\right]\right)}
\end{gathered}
$$

Peluang perpindahan state dibentuk ke dalam matriks transisi karena rantai markov pada matriks transisi menyatakan nilai sekarang dipengaruhi oleh nilai pada periode sebelumnya [14]. Matriks peluang transisi dapat dituliskan pada persamaan (20).

$$
\left[P_{i, j}\right]_{i, j \in S}=\left[\begin{array}{cccc}
P_{0,0} & P_{0,1} & \cdots & P_{0, j} \\
P_{1,0} & P_{1,1} & \cdots & P_{1, j} \\
\vdots & \vdots & \ddots & \vdots \\
P_{i, 0} & P_{i, 1} & \cdots & P_{i, j}
\end{array}\right]
$$

Semakin sedikit perpindahan state yang terjadi maka semakin sedikit juga perpindahan pola data, menunjukkan model yang terbentuk baik. Model MSAR juga dapat menghitung lama durasi rata-rata dari masing-masing state. Elemen diagonal dari matriks peluang transisi mengandung informasi mengenai durasi rata-rata yang diharapkan dari suatu state akan bertahan. Durasi rata-rata state dapat dituliskan pada persamaan (21).

$$
E(\vec{D})=\frac{1}{1-P_{j j}}
$$

dimana $P_{j j}$ merupakan diagonal matriks peluang transisi.

\section{F. Uji Signifikansi Parameter}

Pengujian signifikansi parameter dilakukan dengan cara uji parsial terhadap setiap parameter. Berikut merupakan pengujian signifikansi parameter dengan menggunakan hipotesis yang dituliskan sebagai berikut [6].

$H_{0}: \phi_{i}=0$ (parameter tidak signifikan)

$H_{l}: \phi_{i} \neq 0$ (parameter signifikan)

Statistik uji yang digunakan dituliskan pada persamaan (22).

$$
t=\frac{\hat{\phi}_{i}}{S E\left(\hat{\phi}_{i}\right)}
$$

Keputusan yang didapatkan akan Tolak $\mathrm{H}_{0}$ jika $|t|>t_{\alpha, d f}$ atau $p$-value $<\alpha$.

\section{G. Akaike's Information Criterion (AIC)}

Akaike's Information Criterion digunakan sebagai kriteria pemilihan model terbaik, dikarenakan kriteria ini konsisten dalam menduga parameter model. AIC dapat dituliskan pada persamaan (23) [15].

$$
A I C=-2 \log (L)+2 k
$$

dimana $L$ merupakan nilai maksimum fungsi likelihood, $k$ merupakan banyaknya parameter pada model.

\section{H. Evaluasi Hasil Klasifikasi}

Pengukuran ketepatan klasifikasi dilakukan untuk melihat performa klasifikasi yang telah dilakukan. Ketepatan klasifikasi dapat dievaluasi dengan menghitung jumlah kelas positif yang terklasifikasi dengan benar (true positive), jumlah kelas negatif yang terklasifikasi dengan benar (true negative), jumlah kelas negatif yang salah terklasifikasi ke dalam kelas positif (false positive) atau jumlah kelas positif yang salah terklasifikasi ke dalam kelas negatif (false negative) [16].

Keempat jenis perhitungan ini dapat dilihat melalui sebuah matriks yang sering disebut dengan confusion matrix. Penilaian ketepatan klasifikasi untuk multiclass classification didefinisikan perkelas secara individual.

\begin{tabular}{|c|c|c|c|c|c|}
\hline \multirow{2}{*}{$\begin{array}{c}\text { Kelas } \\
\text { Aktual }\end{array}$} & \multicolumn{4}{|c|}{ Kelas Prediksi } & \multirow{2}{*}{ Total } \\
\hline & $C_{1}$ & $C_{1}$ & $C_{1}$ & $C_{1}$ & \\
\hline$C_{1}$ & $n_{11}$ & $n_{12}$ & $n_{13}$ & $n_{14}$ & $n_{1}$ \\
\hline$C_{2}$ & $n_{21}$ & $n_{22}$ & $n_{23}$ & $n_{24}$ & $n_{2}$ \\
\hline$C_{3}$ & $n_{31}$ & $n_{32}$ & $n_{33}$ & $n_{34}$ & $n_{3}$ \\
\hline$C_{4}$ & $n_{41}$ & $n_{42}$ & $n_{43}$ & $n_{44}$ & $n_{4}$ \\
\hline Total & $n .1$ & $n .2$ & $n .3$ & $n .4$ & $N .$. \\
\hline
\end{tabular}
Kualitas keseluruhan klasifikasi dapat dinilai dengan dua cara yakni melalui rata-rata dari tiap kriteria yang dihitung untuk setiap kelasnya (macro-averaging) atau jumlah penghitungan untuk mendapatkan kumulatif TP, FN, TN, dan FP (micro-averaging) [16]. Nilai TP pada kasus multiclass classification terdapat pada diagram matriks yang digambarkan pada Tabel 1.

Tabel 1 Confusion Matrix Multiclass

Pada kasus multiclass kinerja klasifikasi dapat diukur dengan menggunakan accuracy, precision, sensitivity, dan Fscore. Accuracy adalah banyaknya pengamatan yang terklasifikasi secara tepat. Fscore didapatkan dari nilai kombinasi antara precision dan sensitivity. Precision adalah banyaknya pengamatan yang tepat terprediksi positif dari keseluruhan dengan hasil prediksi positif, sedangkan sensitivity adalah banyaknya pengamatan yang tepat diklasifikasikan sesuai kategorinya [16]. Perhitungan accuracy, precision, sensitivity, dan Fscore dapat dilakukan dengan menggunakan persamaan-persamaan berikut.

$$
\begin{gathered}
\text { accuracy }=\frac{1}{K} \sum_{k=1}^{K} \frac{T P_{k}+T N_{k}}{T P_{k}+F N_{k}+F P_{k}+T N_{k}} \\
\text { sensitivity }=\frac{1}{K} \sum_{k=1}^{K} \frac{T P_{k}}{T P_{k}+F N_{k}} \\
\text { precision }=\frac{1}{K} \sum_{k=1}^{K} \frac{T P_{k}}{T P_{k}+F P_{k}} \\
F=\frac{2 \times \text { precision } \times \text { sensitivity }}{\text { precision }+ \text { sensitivity }}
\end{gathered}
$$




\section{Cryptocurrency}

Istilah cryptocurrency tercipta pada tahun 1982, seseorang yang bernama David Chaum mempublikasikan ide pembuatan sebuah metode pembayaran bebasis kriptografi yang dapat menjaga kerahasiaan data pemiliknya, karena tidak bisa dilacak oleh pihak ketiga [17]. Kemudian pada tahun 2008 seorang programmer yang bernama Satoshi Nakamoto membuat mata uang digital berbasis kriptografi yang diberi nama bitcoin [18]. Bitcoin inilah yang menjadi pionir munculnya jenis cryptocurrency baru seperti ethereum dan ripple. Beberapa jenis cryptocurrency memiliki jumlah pasokan yang terbatas, seperti halnya bitcoin 21 juta dan ripple 100 miliar. Keterbatasan pasokan ini menjadi salah satu faktor berubahnya harga cryptocurrency. Fluktuasi pada harga cryptocurrency dapat merubah harga secara signifikan dalam waktu yang sangat cepat.

Cryptocurrency di Indonesia diakui keberadaanya sejak tanggal 2 Oktober 2018 dengan terbitnya Peraturan Menteri Perdagangan Republik Indonesia No. 99 Tahun 2018 Tentang Kebijakan Umum Penyelenggaraan Perdangangan Berjangka Aset Kripto (Crypto Asset), yang mana pada pasal 1 berbunyi aset kripto ditetapkan sebagai Komoditi yang dapat dijadikan Subjek Kontrak Berjangka yang diperdagangkan di Bursa Berjangka.

\section{METODOLOGI PENELITIAN}

\section{A. Sumber Data}

Data yang digunakan dalam penelitian ini adalah data sekunder yang diperoleh dari situs CryptoCompare. Data diambil pada tanggal 1 Februari 2020 dari situs https://www.cryptocompare.com. Data yang digunakan berupa harga harian cryptocurrency dengan nilai kapitalisasi pasar tertinggi yang dimulai dari tanggal 1 September 2015 sampai 31 Januari 2020. Jenis cryptocurrency yang digunakan yaitu bitcoin, ethereum, dan ripple.

\section{B. Variabel Penelitian}

Variabel penelitian yang digunakan adalah harga harian ketiga jenis cryptocurrency dengan nilai kapitalisasi pasar tertinggi. Variabel penelitian tercantum pada Tabel 2.

Tabel 2 Variabel Penelitian

\begin{tabular}{cll}
\hline Variabel & \multicolumn{1}{c}{ Keterangan } & Skala \\
\hline $\mathrm{Y}_{1}$ & Harga Bitcoin $(\mathrm{BTC})$ & Rasio \\
$\mathrm{Y}_{2}$ & Harga Ethereum $(\mathrm{ETH})$ & Rasio \\
$\mathrm{Y}_{3}$ & Harga Ripple $(\mathrm{XRP})$ & Rasio \\
\hline
\end{tabular}

Ketiga variabel penelitian ini tidak terkait satu sama lain dan data dibagi menjadi data training dan testing. Struktur data pada penelitian ini ditunjukkan pada Tabel 3 .

Tabel 3 Struktur Data Penelitian

\begin{tabular}{ccccc}
\hline Data & Tanggal & $\mathbf{Y}_{\mathbf{1}}$ & $\mathbf{Y}_{\mathbf{2}}$ & $\mathbf{Y}_{\mathbf{3}}$ \\
\hline \multirow{6}{*}{ Training } & $01-09-2015$ & $\mathrm{Y}_{1,1}$ & $\mathrm{Y}_{2,1}$ & $\mathrm{Y}_{3,1}$ \\
& $02-09-2015$ & $\mathrm{Y}_{1,2}$ & $\mathrm{Y}_{2,2}$ & $\mathrm{Y}_{3,2}$ \\
& $28-02-2019$ & $\mathrm{Y}_{1,1277}$ & $\mathrm{Y}_{2,1614}$ & $\mathrm{Y}_{3,1614}$ \\
\hline \multirow{5}{*}{ Testing } & $01-03-2019$ & $\mathrm{Y}_{1,1278}$ & $\mathrm{Y}_{2,1278}$ & $\mathrm{Y}_{3,1278}$ \\
& $02-03-2019$ & $\mathrm{Y}_{1,1279}$ & $\mathrm{Y}_{2,1279}$ & $\mathrm{Y}_{3,1279}$ \\
& $\vdots$ & $\vdots$ & $\vdots$ & $\vdots$ \\
& $31-01-2020$ & $\mathrm{Y}_{1,1614}$ & $\mathrm{Y}_{2,1614}$ & $\mathrm{Y}_{3,1614}$ \\
\hline
\end{tabular}

\section{Langkah Analisis}

Langkah-langkah analisis dalam penelitian ini dituliskan sebagai berikut :

1. Mengumpulkan data harga harian bitcoin, ethereum, dan ripple dengan cara mengunduh data pada situs https://cryptocompare.com.

2. Melakukan eksplorasi data dengan menghitung statistika deskriptif dan membuat plot time series pada data harga harian bitcoin, ethereum, dan ripple untuk mengetahui karakteristik data, penghitungan statistika deskriptif antara lain menghitung mean, varians, nilai maksimum, dan nilai minimum.

3. Membagi data harga harian bitcoin, ethereum, dan ripple menjadi data training dan testing dengan proporsi 80:20.

4. Melakukan uji stasioneritas pada masing-masing data training harga harian bitcoin, ethereum, dan ripple.

a. Membuat plot Autocorrelation Function (ACF) data penelitian.

b. Melakukan uji root test dengan uji Augmented Dickey-Fuller (ADF) untuk menguji stasioner terhadap mean.

c. Membuat plot box-cox data penelitian untuk menguji stasioner terhadap varians.

5. Jika data tidak stasioner, maka perlu melakukan transformasi log return dengan cara differencing log data penelitian.

6. Menaksir estimasi parameter model Markov Switching Autoregressive dengan menggunakan nilai states/regime dari 2 hingga 9 states serta melakukan perulangan sebanyak 5 kali setiap state, pada setiap data penelitian dengan algoritma Expectation-Maximization (EM).

7. Memilih model terbaik untuk setiap harga bitcoin, ethereum, dan ripple berdasarkan nilai AIC minimum.

8. Menentukan anggota tiap state model terbaik untuk setiap harga bitcoin, ethereum, dan ripple dengan menggunakan data prediksi $\operatorname{AR}(1)$ dan data testing.

9. Membandingkan performa klasifikasi state pada setiap model terbaik antara state data prediksi AR(1) dan state data testing berdasarkan nilai accuracy, precision, sensitivity, dan Fscore.

10. Menarik kesimpulan dan saran terkait hasil analisis yang telah dilakukan.

\section{ANALISIS DAN PEMBAHASAN}

\section{A. Eksplorasi Data}

Statistika deskriptif harga harian ketiga jenis cryptocurrency dari tanggal 1 September 2015 sampai tanggal 31 Januari 2020 ditunjukkan pada Tabel 4.

Tabel 4 Statistika Deskriptif Harga Harian Cryptocurrency

\begin{tabular}{lllll}
\hline Variabel & $\begin{array}{l}\text { Rata- } \\
\text { rata }\end{array}$ & Varians & $\begin{array}{l}\text { Nilai } \\
\text { Maksimum }\end{array}$ & $\begin{array}{l}\text { Nilai } \\
\text { Minimum }\end{array}$ \\
\hline Bitcoin & 4583,6 & 15644068 & 19346,6 & 226,2 \\
Ethereum & 205,19 & 57480,4558 & 1385,02 & 0,42 \\
Ripple & 0,2678 & 0,11021 & 2,78 & 0,0039 \\
\hline
\end{tabular}

Cryptocurrency dengan rata-rata harga harian tertinggi dari tanggal 1 September 2015 sampai 31 Januari 2020 adalah bitcoin yaitu sebesar 4.583,6 dolar Amerika. Disusul dengan ethereum dengan rata-rata harga sebesar 205,19 dan ripple sebesar 0,2678 dolar Amerika. Harga harian bitcoin sangat berfluktuatif dilihat dari nilai varians sebesar 15.644.068, dengan harga terendah 226,2 dolar dan harga tertinggi 19.346,6 dolar. 
Puncak harga tertinggi bitcoin terjadi pada tanggal 17 Desember 2017, untuk harga tertinggi ethereum pada tanggal 14 Januari 2018, sedangkan harga tertinggi ripple tanggal 8 Januari 2018. Harga terendah bitcoin terjadi pada tanggal 4 September 2015, untuk harga ethereum pada tanggal 22 Oktober 2015, sedangkan harga ripple tanggal 1 Desember 2015. Pola data harian cryptocurrency dapat dilihat degan plot time series. Berikut plot time series dari ketiga data harian cryptocurrency.

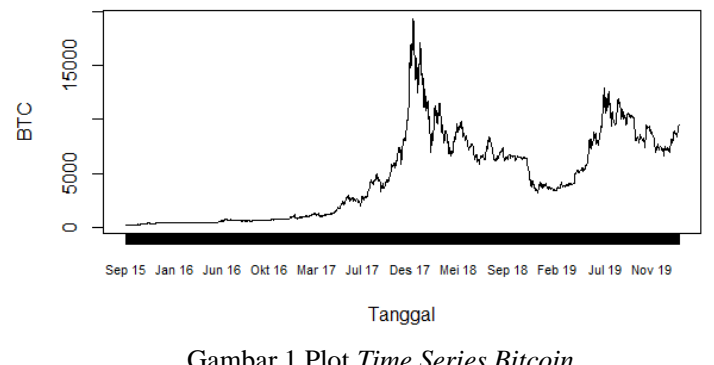

Plot time series bitcoin yang ditunjukkan Gambar 1 terdapat pola stagnan di bulan September 2015 hingga Agustus 2017, pada bulan ini munculnya pergerakan harga bitcoin yang mulai merangkak naik hingga mencapai puncaknya dengan harga 19.346,6 dolar Amerika di pertengahan bulan Desember 2017. Namun harga harian bitcoin tidak mampu meningkat lagi, bahkan terjadi tren menurun secara terus menerus hingga bulan Januari 2019, dan mulai merangkak naik kembali setelahnya, namun harga bitcoin tidak bisa melebihi 13.000 dolar Amerika.

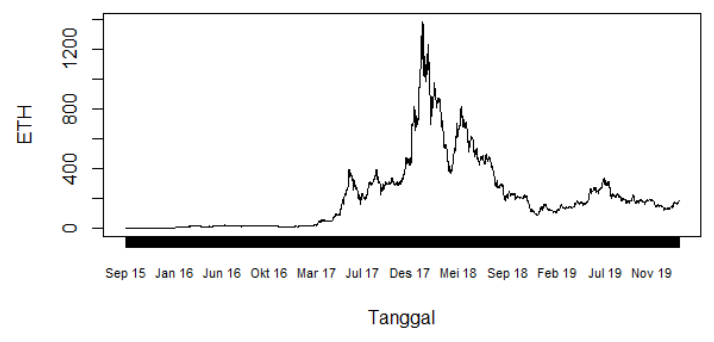

Gambar 2 Plot Time Series Ethereum

Plot time series ethereum yang ditunjukkan Gambar 2 tidak berbeda dengan pola data harga bitcoin yang stagnan, namun pada bulan Mei 2017 harga ethereum mulai menunjukkan kenaikan harga walaupun sesekali mengalami penurunan harga hingga mencapai puncak tertinggi harga ethereum pada bulan Januari 2018. Harga ethereum mengalami penurunan harga yang drastis pada bulan April 2018, sempat berbalik harga di bulan Mei 2018 namun tidak bertahan lama harga ethereum kembali turun secara terus menerus. Kemudian harga ethereum bulan Januari 2019 hingga Januari 2020 berfluktuasi di range harga ethereum 100 sampai 330 dolar Amerika.

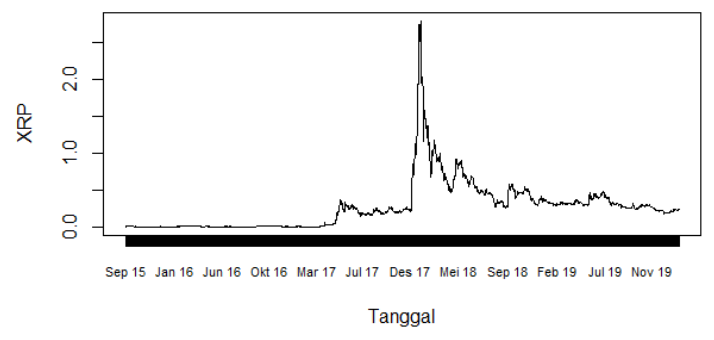

Gambar 3 Plot Time Series Ripple

Pola data harga ripple tidak jauh berbeda dengan 2 harga cryptocurrency sebelumnya, yaitu terdapat pola stagnan hingga di akhir bulan Maret 2017, pada titik inilah harga ripple mulai menunjukkan pergerakannya. Berdasarkan gambar 3 harga ripple mengalami kenaikan harga yang signifikan dari bulan Desember 2017 hingga mencapai puncaknya pada Januari 2018. Serupa dengan kenaikan harga yang signifikan dengan cepat hal ini juga terjadi pada penurunan harga yang cepat juga. Harga ripple mulai mengalami fluktuasi yang normal pada bulan Juni 2018 hingga Januari 2020 dengan batas bawah harga 0,18 dan batas atas 0,58 dolar Amerika.

\section{B. Uji Stasioneritas}

Stasioneritas dapat diartikan tidak terdapat perubahan yang drastis pada data. Sebelum melakukan uji stasioneritas data penelitian dibagi menjadi dua bagian terlebih dahulu, yaitu data training dan data testing. Data training dimulai dari tanggal 1 September 2015 sampai tanggal 28 Februari 2019, sedangkan data testing tanggal 1 Maret 2019 hingga 31 Januari 2020. Data yang digunakan pada uji stasioneritas dan pembentukan model yaitu data training. Maka dibentuklah plot ACF untuk melihat ketidakstasioneran data.

(a)

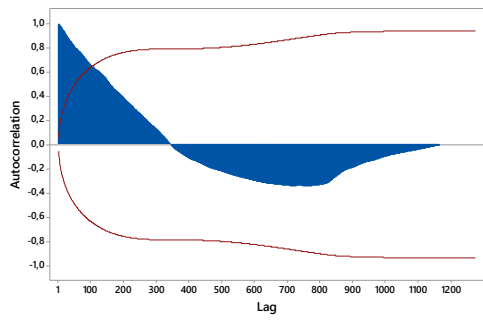

(b)

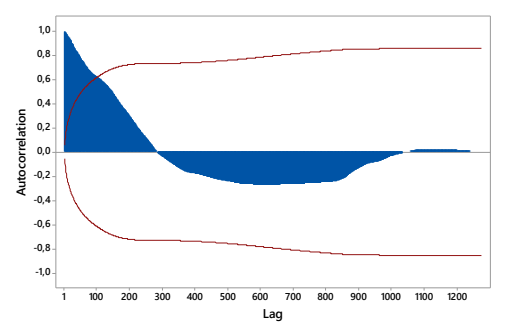

(c)

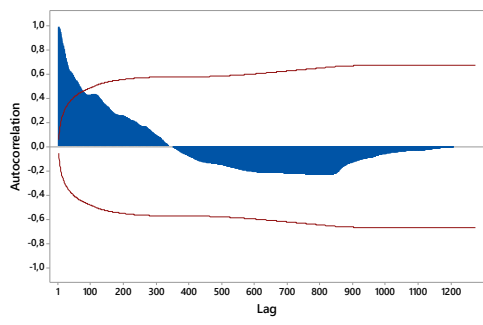

Gambar 4 Plot ACF (a) Bitcoin (b) Ethereum (c) Ripple

Terlihat bahwa plot ACF data harga harian ketiga cryptocurrency cenderung turun secara lambat sehingga dapat dikatakan tidak stasioner terhadap mean dan varians. Alternatif lain untuk mengetahui ketidakstasioneran data dengan melakukan uji unit root dengan uji Augmented Dickey-Fuller (ADF).

\begin{tabular}{ccc}
\multicolumn{3}{c}{ Tabel 5 Uji ADF Harga Harian Cryptocurrency } \\
\hline Variabel & Dickey-Fuller & p-value \\
\hline Bitcoin & $-2,2512$ & 0,472 \\
Ethereum & $-1,411$ & 0,827 \\
Ripple & $-3,6033$ & 0,032 \\
\hline
\end{tabular}

Hasil uji ADF pada Tabel 5 menunjukkan adanya ketidakstasioneran data terhadap mean pada harga harian bitcoin dan ethereum, karena p-value dari kedua variabel tersebut lebih dari $\alpha(0,05)$. Kemudian untuk mengetahui stasioner atau tidaknya data terhadap varians dengan 
membuat plot box-cox, yang ditampilkan pada Gambar 5 sebagai berikut.

(a)

(b)
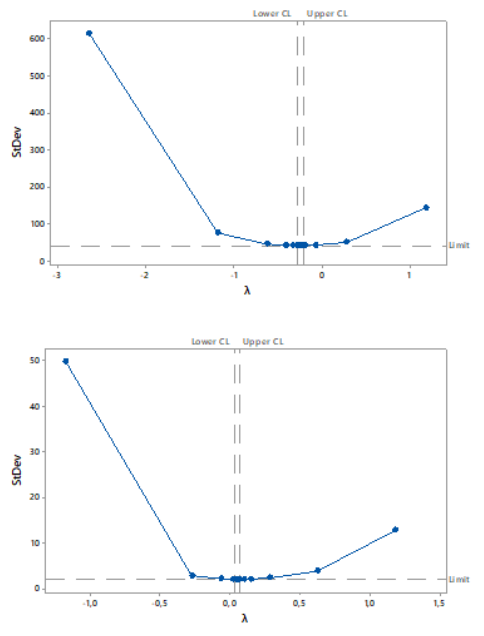

(c)

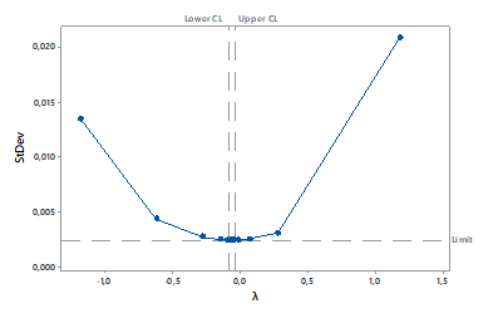

Gambar 5 Plot Box-Cox (a) Bitcoin (b) Ethereum (c) Ripple

Dari ketiga plot box-cox diatas tidak ada harga harian yang nilai lambdanya 1 , maka dapat dikatakan ketiga harga harian diatas tidak stasioner terhadap varians. Data yang tidak stasioner tersebut dapat diatasi dengan transformasi $l o g$ return. Berikut merupakan hasil uji ADF setelah dilakukan transformasi.

Tabel 6 Uji ADF Transformasi Log Return Harga Harian Cryptocurrency

\begin{tabular}{ccc}
\hline Variabel & Dickey-Fuller & p-value \\
\hline Bitcoin & $-9,9126$ & $<0,01$ \\
Ethereum & $-9,8305$ & $<0,01$ \\
Ripple & $-9,1311$ & $<0,01$ \\
\hline
\end{tabular}

Hasil uji ADF setelah transformasi yang dapat dilihat pada Tabel 6 menunjukkan ketiga data sudah stasioner, karena $p$-value dari ketiga variabel tersebut kurang dari $\alpha(0,05)$.

\section{Markov Switching Autoregressive Bitcoin}

Data harga harian bitcoin merupakan data yang paling drastis dalam perubahan harganya dibandingkan kedua variabel lainnya. Hal ini dapat dilihat dari pola plot time series bitcoin yang memiliki 2 puncak, serta dapat dilihat juga dari nilai varians yang sangat besar. Percobaan model Markov Switching Autoregressive (MSAR) pada bitcoin dengan state 2 sampai 9 dapat dilihat pada tabel dibawah.

Tabel 7 Ukuran Kebaikan Model MSAR Bitcoin

\begin{tabular}{cc}
\hline Model & AIC \\
\hline MS(2)AR(1) & $-5157,23$ \\
MS(3)AR(1) & $-5266,28$ \\
MS(4)AR(1) & $-5300,37$ \\
MS(5)AR(1) & $-5308,62$ \\
MS(6)AR(1) & $-5325,04$ \\
MS(7)AR(1) & $-5331,48$ \\
MS(8)AR(1) & $\mathbf{- 5 3 5 2 , 2 3}$ \\
MS(9)AR(1) & $-5344,10$ \\
\hline
\end{tabular}

Ukuran kebaikan model MSAR bitcoin dapat dilihat pada Tabel 7 menunjukkan 8 state sebagai model terbaik, dikarenakan nilai AIC dari model tersebut lebih kecil dibandingkan model lainnya, dengan model yang terbentuk sebagai berikut.

$$
\left(Y_{1_{t}}-\mu_{s_{t}}\right)=-0.0084\left(Y_{1_{t-1}}-\mu_{s_{t-1}}\right)+e_{t}
$$

dengan rata-rata masing-masing state sebagai berikut.

$$
\mu_{s_{t}} \begin{cases}\mu_{1}=-0.0883, & \mu_{5}=-0.1932 \\ \mu_{2}=-0.0595, & \mu_{6}=-0.2691 \\ \mu_{3}=0.5876, & \mu_{7}=0.0128 \\ \mu_{4}=-0.2762, & \mu_{8}=0.2568\end{cases}
$$

Tabel 8 Esimasi Parameter Model MS(8)AR(1) Bitcoin

\begin{tabular}{crrcc}
\hline Parameter & Koefisien & \multicolumn{1}{c}{ p-value } & Parameter & Koefisien \\
\hline$\hat{\phi}_{1}$ & $-0,0084$ & 0,765 & & \\
$\hat{\mu}_{1}$ & $-0,0883$ & 0,751 & $\sigma_{1}$ & 0,0617 \\
$\hat{\mu}_{2}$ & $-0,0595$ & 0,499 & $\sigma_{2}$ & 0,0213 \\
$\hat{\mu}_{3}$ & 0,5876 & $1,02 \mathrm{e}-06$ & $\sigma_{3}$ & 0,0559 \\
$\hat{\mu}_{4}$ & $-0,2762$ & 0,015 & $\sigma_{4}$ & 0,0647 \\
$\hat{\mu}_{5}$ & $-0,1932$ & $<2,2 \mathrm{e}-16$ & $\sigma_{5}$ & 0,0055 \\
$\hat{\mu}_{6}$ & $-0,2691$ & 0,002 & $\sigma_{6}$ & 0,0231 \\
$\hat{\mu}_{7}$ & 0,0128 & 0,809 & $\sigma_{7}$ & 0,0311 \\
$\hat{\mu}_{8}$ & 0,2568 & $<2,2 \mathrm{e}-16$ & $\sigma_{8}$ & 0,0165 \\
\hline
\end{tabular}

Estimasi parameter model MS(8)AR(1) menunjukkan adanya state yang memiliki $p$-value lebih dari $\alpha(0,05)$ yang dapat diartikan koefisien rata-rata pada beberapa state, diantaranya state 1, 2, dan 7 tidak berpengaruh signifikan terhadap model yang terbentuk. Nilai rata-rata dari masingmasing state memiliki nilai yang kecil serta mayoritas state yang terbentuk memiliki nilai negatif, menandakan model yang terbentuk lebih sering meningkat pada saat pergantian state. Nilai standar deviasi yang kecil setiap state menandakan pengelompokan data observasi masing-masing state memiliki nilai yang serupa. Hasil output peluang matriks transisi juga dapat digunakan untuk menghitung lama durasi masing-masing state, dapat dilihat pada tabel berikut.

\begin{tabular}{ccc} 
Tabel 9 Lama Durasi Setiap State & Model MS(8)AR(1) Bit \\
\cline { 2 - 3 } State & $\begin{array}{c}\text { Peluang } \\
\text { State }\end{array}$ & $\begin{array}{c}\text { Durasi } \\
\text { Kondisi State }\end{array}$ \\
\hline 1 & 0,145 & 1,170 \\
2 & 0,804 & 5,103 \\
3 & 0,070 & 1,076 \\
4 & 0,101 & 1,112 \\
5 & 0,531 & 2,133 \\
6 & 0,118 & 1,133 \\
7 & 0,142 & 1,166 \\
8 & 0,439 & 1,782 \\
\hline
\end{tabular}

Dapat dilihat pada Tabel 9 bahwa rata-rata lama durasi setiap state memiliki nilai yang serupa, kecuali pada state 2 yang berdurasi 5,103 hari sekaligus menjadi state yang paling lama bertahan. Sedangkan state dengan durasi tercepat terjadi pada state 3 sebesar 1,076 hari.

\section{Markov Switching Autoregressive Ethereum}

Data harga harian ethereum sama halnya dengan bitcoin yang memiliki nilai varians besar. Percobaan model Markov Switching Autoregressive (MSAR) pada ethereum dengan state 2 sampai 9 dapat dilihat pada tabel dibawah.

\begin{tabular}{cc} 
Tabel 10 Ukuran Kebaikan Model MSAR Ethe \\
\cline { 2 - 2 } Model & AIC \\
\hline MS(2)AR(1) & $-3552,46$ \\
MS(3)AR(1) & $-3572,53$ \\
MS(4)AR(1) & $-3621,02$ \\
MS(5)AR(1) & $-3636,36$ \\
MS(6)AR(1) & $-3640,68$ \\
\hline
\end{tabular}


Tabel 10 Ukuran Kebaikan Model MSAR Ethereum (Lanjutan)

\begin{tabular}{cc}
\hline Model & AIC \\
\hline MS(7)AR(1) & $-3652,79$ \\
MS(8)AR(1) & $-3660,69$ \\
MS(9)AR(1) & $\mathbf{- 3 6 6 8 , 5 4}$ \\
\hline
\end{tabular}

Dapat dilihat pada Tabel 10 nilai AIC dari model MSAR ethereum tidak berbeda jauh satu sama lainnya. Nilai AIC terkecil pada data ethereum terjadi ketika menggunakan 9 state, yang menjadikan MS(9)AR(1) model terbaik, dengan model sebagai berikut.

$$
\left(Y_{2_{t}}-\mu_{s_{t}}\right)=-0.0618\left(Y_{2_{t-1}}-\mu_{s_{t-1}}\right)+e_{t}
$$

dengan rata-rata masing-masing state sebagai berikut.

$$
\mu_{s_{t}} \begin{cases}\mu_{1}=0.2837, & \mu_{6}=-0.8234 \\ \mu_{2}=-0.2031, & \mu_{7}=-0.1521 \\ \mu_{3}=-0.1734, & \mu_{8}=0.7313 \\ \mu_{4}=1.1162, & \mu_{9}=0.2993 \\ \mu_{5}=-0.0738, & \end{cases}
$$

Tabel 11 Esimasi Parameter Model MS(9)AR(1) Ethereum

\begin{tabular}{crrcc}
\hline Parameter & Koefisien & \multicolumn{1}{c}{$\boldsymbol{p}$-value } & Parameter & Koefisien \\
\hline$\hat{\phi}_{1}$ & $-0,0618$ & 0,027 & & \\
$\hat{\mu}_{1}$ & 0,2837 & 0,272 & $\sigma_{1}$ & 0,0808 \\
$\hat{\mu}_{2}$ & $-0,2031$ & $2,2 \mathrm{e}-10$ & $\sigma_{2}$ & 0,0233 \\
$\hat{\mu}_{3}$ & $-0,1734$ & 0,390 & $\sigma_{3}$ & 0,0445 \\
$\hat{\mu}_{4}$ & 1,1162 & $1,4 \mathrm{e}-08$ & $\sigma_{4}$ & 0,1010 \\
$\hat{\mu}_{5}$ & $-0,0738$ & 0,004 & $\sigma_{5}$ & 0,0072 \\
$\hat{\mu}_{6}$ & $-0,8234$ & $<2,2 \mathrm{e}-16$ & $\sigma_{6}$ & 0,0264 \\
$\hat{\mu}_{7}$ & $-0,1521$ & 0,037 & $\sigma_{7}$ & 0,1105 \\
$\hat{\mu}_{8}$ & 0,7313 & 0,001 & $\sigma_{8}$ & 0,0529 \\
$\hat{\mu}_{9}$ & 0,2993 & 0,005 & $\sigma_{9}$ & 0,0409 \\
\hline
\end{tabular}

Estimasi parameter model MS(9)AR(1) pada Tabel 11 dapat dilihat koefisien rata-rata yang signifikan, namun masih terdapat rata-rata state yang tidak signifikan, yang terdapat pada state 1 dan state 3 dikarenakan $p$-value dari kedua state tersebut lebih dari $\alpha(0,05)$. Nilai rata-rata pada masing-masing state bervariasi dimana dengan batas bawah dan batas atas secara berturut-turut, sebesar -0,8234 dan 1,1162. Persebaran data masing-masing state pada data log return bagus karena nilai varians yang relatif kecil berada diantara 0,0072 hingga 0,1105. Diagonal peluang matriks transisi dapat digunakan untuk menghitung lama durasi masing-masing state, yang dapat dilihat pada tabel dibawah.

Tabel 12 Lama Durasi Setiap State Model MS(9)AR(1) Ethereum

\begin{tabular}{ccc}
\hline State & $\begin{array}{c}\text { Peluang } \\
\text { State }\end{array}$ & $\begin{array}{c}\text { Durasi } \\
\text { Kondisi State }\end{array}$ \\
\hline 1 & 0,110 & 1,123 \\
2 & 0,170 & 1,205 \\
3 & 0,633 & 2,728 \\
4 & 0,006 & 1,006 \\
5 & 0,384 & 1,624 \\
6 & 0,112 & 1,126 \\
7 & 0,714 & 3,492 \\
8 & 0,184 & 1,226 \\
9 & 0,230 & 1,298 \\
\hline
\end{tabular}

Dapat dilihat pada Tabel 12 bahwa rata-rata lama durasi setiap state memiliki nilai yang relatif sama, mayoritas hanya bertahan 1 hari, kecuali pada state 3 dan 7 . State 7 menjadi yang paling lama bertahan dengan durasi 3,492 hari, sedangkan state 4 dengan durasi tercepat sebesar 1,006 hari.

\section{E. Markov Switching Autoregressive Ripple}

Berbanding terbalik dengan data harga harian bitcoin yang memilki perubahan harga yang sangat signifikan data harga harian ripple menjadi data yang stabil pergerakannya jika dilihat dari nilai varians yang kecil, yaitu sebesar 0,11 . Percobaan model Markov Switching Autoregressive (MSAR) pada data ripple dengan jumlah state yang digunakan antara 2 hingga 9 state dapat dilihat pada tabel dibawah.

\begin{tabular}{cc} 
Tabel 13 Ukuran Kebaikan Model MSAR Ripple \\
\cline { 2 - 2 } Model & AIC \\
\hline MS(2)AR(1) & $-3591,36$ \\
MS(3)AR(1) & $-3727,43$ \\
MS(4)AR(1) & $-3744,04$ \\
MS(5)AR(1) & $-3759,00$ \\
MS(6)AR(1) & $-3748,45$ \\
MS(7)AR(1) & $-3771,65$ \\
MS(8)AR(1) & $\mathbf{- 3 7 8 5 , 5 1}$ \\
MS(9)AR(1) & $-3774,12$ \\
\hline
\end{tabular}

Nilai AIC state 8 dan 9 model Markov Switching Autoregressive (MSAR) pada data ripple menunjukkan nilai AIC terkecil ketika menggunakan 8 state, sama halnya seperti model MSAR bitcoin menggunakan 8 state sebagai model terbaik, dan model yang terbentuk sebagai berikut.

$$
\left(Y_{3_{t}}-\mu_{s_{t}}\right)=-0.1068\left(Y_{3_{t-1}}-\mu_{s_{t-1}}\right)+e_{t}
$$

dengan rata-rata masing-masing state sebagai berikut.

$$
\mu_{s_{t}} \begin{cases}\mu_{1}=-0.2978, & \mu_{5}=-0.1949 \\ \mu_{2}=0.4171, & \mu_{6}=-0.6451 \\ \mu_{3}=0.2571, & \mu_{7}=0.5524 \\ \mu_{4}=-0.1822, & \mu_{8}=-0.3453\end{cases}
$$

Tabel 14 Esimasi Parameter Model MS(8)AR(1) Ripple

\begin{tabular}{crrcc}
\hline Parameter & Koefisien & \multicolumn{1}{c}{ p-value } & Parameter & Koefisien \\
\hline$\hat{\phi}_{1}$ & $-0,1068$ & 0,0001 & & \\
$\hat{\mu}_{1}$ & $-0,2978$ & 0,077 & $\sigma_{1}$ & 0,0608 \\
$\hat{\mu}_{2}$ & 0,4171 & 0,422 & $\sigma_{2}$ & 0,0602 \\
$\hat{\mu}_{3}$ & 0,2571 & 0,064 & $\sigma_{3}$ & 0,0495 \\
$\hat{\mu}_{4}$ & $-0,1822$ & 0,043 & $\sigma_{4}$ & 0,0168 \\
$\hat{\mu}_{5}$ & $-0,1949$ & $9,5 \mathrm{e}-06$ & $\sigma_{5}$ & 0,0263 \\
$\hat{\mu}_{6}$ & $-0,6451$ & $<2,2 \mathrm{e}-16$ & $\sigma_{6}$ & 0,0397 \\
$\hat{\mu}_{7}$ & 0,5524 & 0,049 & $\sigma_{7}$ & 0,0222 \\
$\hat{\mu}_{8}$ & $-0,3453$ & $5,9 \mathrm{e}-05$ & $\sigma_{8}$ & 0,0897 \\
\hline
\end{tabular}

Estimasi parameter model MS(8)AR(1) pada Tabel 14 dapat diketahui mayoritas state memiliki $p$-value kurang dari $\alpha(0,05)$, sedangkan state 1,2 , dan 3 tidak berpengaruh signifikan terhadap model yang terbentuk karena $p$-value lebih dari $\alpha(0,05)$. Nilai rata-rata dari masing-masing state memiliki nilai yang hampir sama. Diagonal matriks peluang transisi selanjutnya digunakan untuk menghitung lama durasi masing-masing state yang dapat dilihat pada tabel dibawah.

Tabel 15 Lama Durasi Setiap State Model MS(8)AR(1) Ripple

\begin{tabular}{ccc}
\hline State & $\begin{array}{c}\text { Peluang } \\
\text { State }\end{array}$ & $\begin{array}{c}\text { Durasi } \\
\text { Kondisi State }\end{array}$ \\
\hline 1 & 0,064 & 1,068 \\
2 & 0,268 & 1,366 \\
3 & 0,224 & 1,289 \\
4 & 0,826 & 5,740 \\
5 & 0,296 & 1,421 \\
6 & 0,096 & 1,107 \\
7 & 0,541 & 2,179 \\
8 & 0,127 & 1,145 \\
\hline
\end{tabular}

Lama durasi state ripple yang ditunjukkan pada Tabel 15 cenderung berada di antara 1-2 hari, namun tidak halnya dengan state 4 dengan lama durasi 5,74 hari sekaligus menjadi yang terlama dan state 1 menjadi durasi tercepat.

\section{F. Perbandingan Performa Klasifikasi State}

Sebelum melakukan perbandingan performa klasifikasi state model Markov Switching Autoregressive (MSAR) maka 
diperlukan data aktual dan data prediksi untuk diterapkan ke dalam model MSAR. Data yang digunakan pada data aktual yaitu data testing, sedangkan data prediksi menggunakan data ramalan model Autoregressive (AR) berorde 1. Hasil anggota masing-masing state dengan data ramalan $\mathrm{AR}(1)$ tersebut dibandingkan dengan data testing untuk mengetahui performa klasifikasi state model MSAR yang dapat dilihat pada tabel sebagai berikut.

Tabel 16 Perbandingan Performa Klasifikasi State Model MSAR

\begin{tabular}{ccccc}
\hline Variabel & Akurasi & $\begin{array}{c}\text { Precision } \\
\text { Macro }\end{array}$ & $\begin{array}{c}\text { Sensitivity } \\
\text { Macro }\end{array}$ & $\begin{array}{c}\text { Fscore } \\
\text { Macro }\end{array}$ \\
\hline BTC & $42,90 \%$ & $47,05 \%$ & $41,96 \%$ & $37,66 \%$ \\
ETH & $65,98 \%$ & $43,97 \%$ & $65,11 \%$ & $52,49 \%$ \\
XRP & $\mathbf{8 5 , 8 0 \%}$ & $\mathbf{6 3 , 3 4 \%}$ & $\mathbf{6 7 , 6 7 \%}$ & $\mathbf{6 5 , 4 3 \%}$ \\
\hline
\end{tabular}

Nilai performa klasifikasi state masing-masing model MSAR ditunjukkan pada Tabel 16, dapat dilihat bahwa model MSAR dengan variable ripple menghasilkan performa lebih baik dibandingkan bitcoin dan ethereum. Hal ini dapat dilihat dari keempat pengukuran hasil klasifikasi pada variabel ripple lebih baik dibandingkan dua variabel lainnya. Dapat dikatakan juga perbandingan klasifikasi antara data prediksi AR(1) dengan data testing banyak memiliki kesamaan klasifikasi state. Maka model MS(8)AR(1) pada data ripple menjadi model terbaik dalam hal klasifikasi state.

\section{KESIMPULAN DAN SARAN}

Kesimpulan yang diperoleh dari hasil analisis yang telah dilakukan adalah sebagai berikut.

1. Cryptocurrency dengan rata-rata harga paling besar adalah bitcoin yaitu 4583,6 dolar. Harga harian bitcoin paling berfluktuatif dilihat dari nilai varians sebesar 15644068, dengan harga terendah 226,2 dolar dan harga tertinggi 19346 dolar. Pola data bitcoin memiliki 2 puncak setelah terjadi penurunan harga yang signifikan sebelumnya, berbeda dengan pola data ethereum setelah mengalami kenaikan harga yang signifikan harga cenderung turun setiap waktunya, sedangkan pola data ripple mengalami peningkatan harga yang sangat cepat dan besar, begitu pula dengan penurunan harganya, namun harganya cenderung stabil setelah itu.

2. Model Markov Switching Autoregressive (MSAR) yang terpilih berdasarkan nilai AIC minimum diperoleh data bitcoin dan ripple menggunakan model MS(8)AR(1), sedangkan ethereum menggunakan model MS(9)AR(1).

3. Nilai kebaikan hasil klasifikasi state setiap model terbaik ketiga jenis cryptocurrency diperoleh data ripple yang memiliki nilai kinerja paling baik dengan nilai akurasi sebesar $85,8 \%$.

Berdasarkan kesimpulan yang diperoleh, dapat dirumuskan saran sebagai pertimbangan penelitian selanjutnya yaitu dengan menentukan model Autoregressive yang sesuai dengan data pengamatan, serta semua parameter dalam uji signifikansi terpenuhi agar menghasilkan model yang lebih baik.

\section{DAFTAR PUSTAKA}

[1] I. Nubika, BITCOIN: Mengenal Cara Baru Berinvestasi Generasi Milenial, Bantul: Genesis Learning, 2018.

[2] E. Dourado dan J. Brito, "Cryptocurrency," The New Palgrave Dictionary of Economics, Online Edition, 2014.
[3] S. Nakamoto, "Bitcoin: A Peer-to-Peer Electronic Cash System," 2009. [Online]. Available: http://bitcoin.org. [Diakses 21 Januari 2020].

[4] CryptoCompare, "Live Cryptocurrency Prices, Trades, and Forums," 2020. [Online]. Available: http://cryptocompare.com. [Diakses 16 Januari 2020].

[5] M. P. Clements dan H.-M. Krolzig, "A Comparison of the Forecast Performance of Markov-Switching and Threshold Autoregressive Models of US GNP," University of Warwick, Coventry, 1997.

[6] W. W. S. Wei, Time Series Analysis: Univariate and Multivariate Methods, Second Edition, New York: Pearson, 2006.

[7] R. Adhikari dan R. K. Agrawal, An Introductory Study on Time Series Modeling and Forecasting, Saarbrucken: LAP Lambert Academic Publishing, 2013.

[8] R. S. Tsay, Analysis of Financial Time Series, Canada: John Wiley \& Sons, 2002.

[9] J. D. Cryer dan K.-S. Chan, Time Series Analysis with Applications in R, New York: Springer Science+Business Media, LLC, 2008.

[10] A. Katchova, "Time Series ARIMA Models," 2013. [Online].

Available: http://sites.google.com/site/econometricsacademy. [Diakses 22 Januari 2020].

[11] S. Fruhwirth-Schnatter, Finite Mixture and Markov Switching Models, New York: Springer, 2006.

[12] J. D. Hamilton, "A New Approach to the Economic Analysis of Nonstationary Time Series and the Business Cycle," Econometrica, vol. 57, no. 2, pp. 357384, 1989.

[13] C.-J. Kim, "Dynamic Linear Models with Markov Switching," Journal of Econometrics, vol. 60, pp. 122, 1994.

[14] C.-J. Kim dan C. R. Nelson, State-Space Models with Regime Switching: Classical and Gibbs-Sampling Approaches with Applications, Cambridge: The MIT Press, 1999.

[15] H. Akaike, "A Bayesian Analysis of the Minimum AIC Procedure,” Ann. Inst. Statist. Math., vol. 30, pp. 9-14, 1978.

[16] M. Sokolova dan G. Lapalme, "A Systematic Analysis of Performance Measures for Classification Tasks," Information Processing and Management, vol. 45, pp. 427-437, 2009.

[17] D. Chaum, "Blind Signatures for Untraceable Payments," Advances in Cryptology Proceedings of Crypto 82, pp. 199-203, 1982.

[18] F. Mulyanto, "Pemanfaatan Cryptocurrency Sebagai Penerapan Mata Uang Rupiah Kedalam Bentuk Digital Menggunakan Teknologi Bitcoin,” Indonesian Journal on Networking and Security, pp. 19-26, 2015. 